\title{
THE LIFE AND LEGACY OF THOMAS MIDGLEY JR.
}

\author{
by Frank T. Edelmann
}

(with two text-figures and four plates)

\begin{abstract}
Edelmann, F.T. 2016 (31:viii): The life and legacy of Thomas Midgley Jr. Papers and Proceedings of the Royal Society of Tasmania 150(1): 45-49. https://doi.org/10.26749/rstpp.150.1.45 Chemisches Institut der Otto-von-Guericke-Universität Magdeburg, Universitätsplatz 2, 39106 Magdeburg, Germany. Email: frank.edelmann@ovgu.de.
\end{abstract}

\begin{abstract}
Although little known to the general public, Thomas Midgley Jr., an American chemist and inventor, made two inventions which had fatal impacts on the Earth's atmosphere, namely tetraethyl lead as an additive to fuels and Freon 12 as a refrigerant.
\end{abstract}

Key Words: Thomas Midgley Jr., lead, tetraethyl lead, leaded fuel, Freon 12, CFCs, ozone hole.

\section{INTRODUCTION}

Thomas Midgley Jr. was an American chemist and inventor whose inventions continue to influence all of us today. He was born on 18 May 1889, in Beaver Falls, Pennsylvania. His intention was to help mankind, but two of his greatest inventions threatened life on Earth. In the end he was killed by his last invention (Wiener Zeitung 2014, Spiegel Online 2014, Wikipedia 2016).

\section{THE FIRST INVENTION}

Thomas Midgley Jr. (pl. 1) was born into a family of inventors, notably in the field of automobile tyres. He grew up in Columbus, Ohio, and graduated in 1911 as a mechanical engineer from Cornell University. During his time at Cornell he developed a great interest in experimentation which was to characterise his life (Midgley, Jr. 1942).

In 1916, Midgley began working at General Motors under the direction of Charles Kettering (Kettering 1947). A significant practical problem which he tackled at General Motors was the so-called "knocking" of combustion engines. Midgley discovered that this noisy engine knock could be stopped by adding certain chemical compounds to the gasoline. Such compounds are called additives. At General Motors, several additives were tested but later discarded for various reasons. For example, testing of aniline as a fuel additive led to noxious odours of the car exhaust gases (Midgley Jr. 1926).

Finally, in 1921, Midgley discovered that tetraethyl lead (or TEL) acts as an outstanding anti-knock agent in gasoline and leads to a greatly improved performance of combustion engines. Thus he was the one who invented leaded gasoline (Midgley IV 2001). In December 1922, Midgley was awarded the Nichols Medal of the American Chemical Society for the "Use of Anti-Knock Compounds in Motor Fuels" (ACS 2016). A major problem with this invention, however, was the well-known high toxicity of lead. The chemical composition of tetraethyl lead is $\mathrm{Pb}\left(\mathrm{C}_{2} \mathrm{H}_{5}\right)_{4}$ (fig. 1).

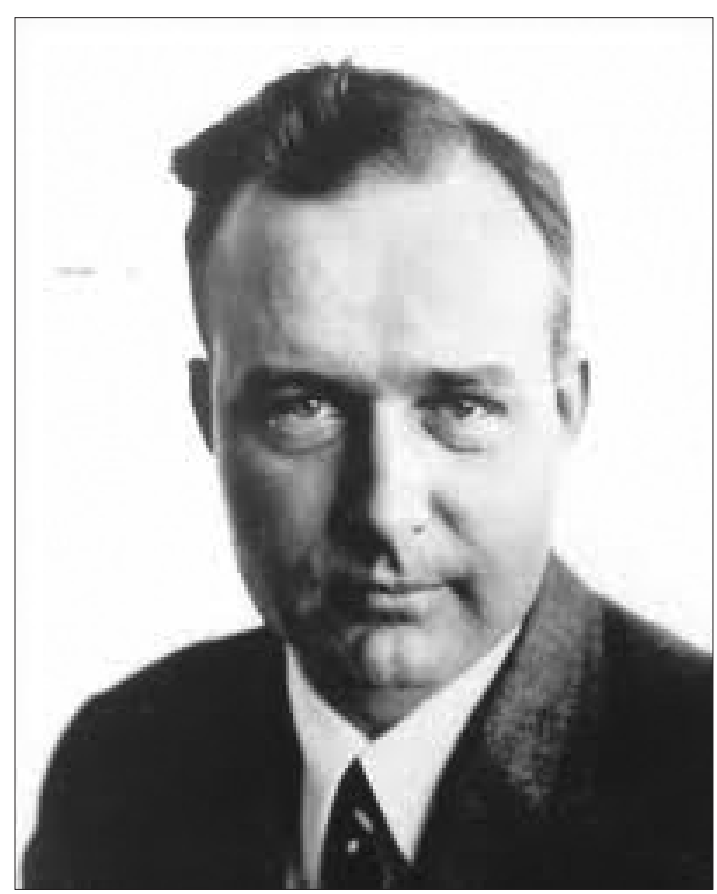

PLATE 1 - Thomas Midgley Jr. (http://science.kukuchew. com/2008/10/21/thomas-midgley-jr/)

This is a so-called organometallic compound of lead, which means that the lead atom is directly bonded to carbon atoms. In this case there are four ethyl groups connected to the lead atom. The physical properties of such organometallic compounds are completely different from those of simple metal salts. For example, lead salts are soluble in water and have high melting points. Therefore, while lead salts are highly toxic when swallowed, they cannot easily pollute the atmosphere. The situation is completely different for organometallic lead compounds such as tetraethyl lead. Tetraethyl lead is a colourless liquid which is easily vaporised. This property of tetraethyl lead was important for its possible use as a fuel additive as it had to be miscible with the gasoline. However, it had the severe disadvantage that it could easily diffuse into the 
<smiles>CC[Pb](CC)(CC)CC</smiles>
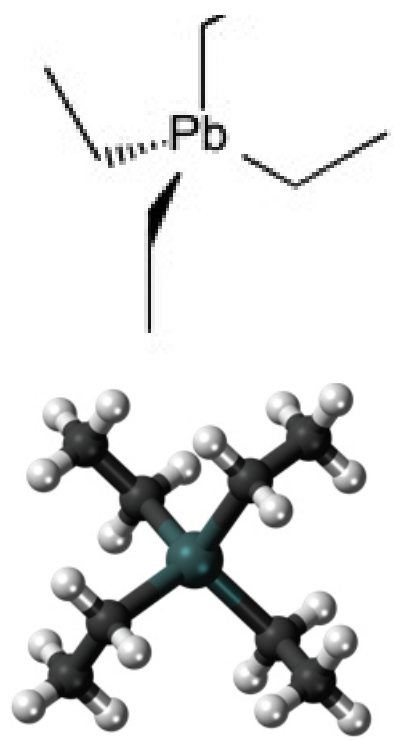

FIG. 1 - Three representations of tetraethyl lead, $\mathrm{Pb}\left(\mathrm{C}_{2} \mathrm{H}_{5}\right)_{4}$.

atmosphere. Even after combustion in the automotive engine, large amounts of lead particles were released into the atmosphere (Markowitz \& Rosner 2003).

At that time, in the 1920s, it was well established that lead compounds are dangerous nerve poisons or neurotoxins and can lead to irreparable damage of the human brain and central nervous system. Workers producing the additive were exposed to severe health hazards. Within the first two months of production, the new plant was plagued by numerous cases of acute lead poisoning, accompanied by visual disorders, hallucinations, insanity, and five deaths in quick succession. All this was accepted by the industry (Markowitz \& Rosner 2003). Too big were the promises of the new, cheap miracle cure for cars and aeroplanes. Cars changed gear faster and performed much more smoothly than before the arrival of TEL. Leaded fuel was first marketed in 1923 at a gas station in Dayton, Ohio (Midgley IV 2001).

Midgley was not only a researcher but also a successful businessman. He became the first general manager of the newly created Ethyl Gasoline Corporation, the company that produced and marketed tetraethyl lead (Midgley IV 2001).

Plate 2 shows promotional signs for leaded fuel on gasoline pumps. It is interesting to note that the full name tetraethyl lead was shortened to ethyl so that the ominous term lead would not show up on the gasoline pump.
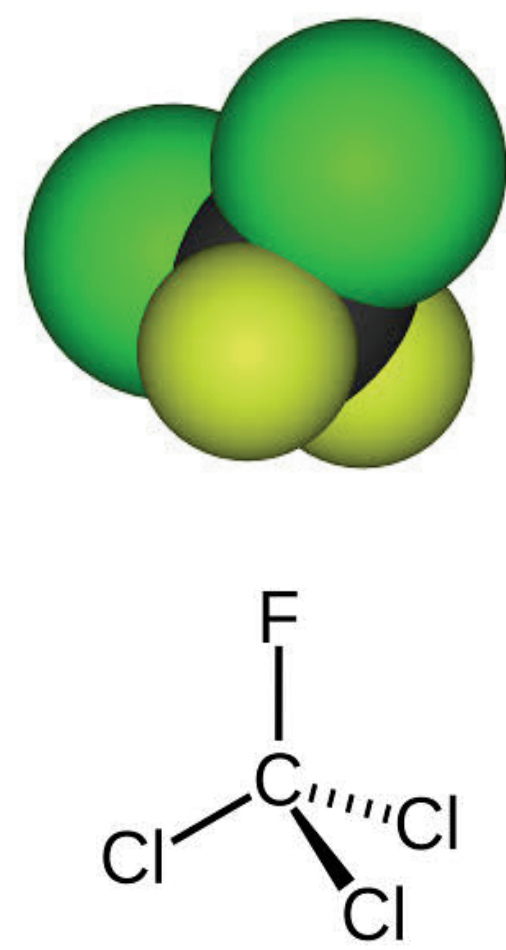

FIG. 2 - Two representations of dichlorodifluoromethane (Freon 12).

Plate 3 illustrates newspaper advertisements of the Ethyl Gasoline Corporation intended to present leaded fuel in a positive light.

However, the toxic effects of lead were generally known and well established. As negative headlines continued, Midgley reacted with a drastic public relations move to demonstrate the harmless nature and apparent safety of TEL: On 30 October 1924 Midgley organised a press conference where, in the presence of numerous journalists, he poured tetraethyl lead over his hands. He also placed a bottle of the dangerous chemical under his nose and inhaled the vapour for 60 seconds. Then he declared: "I could do this every day without getting any health problems whatsoever." (Markowitz \& Rosner 2003). In saying this, Midgley consciously lied to the journalists. Shortly after the press conference, he was diagnosed with serious lead poisoning that took more than a year to cure (Kitman 2000).

Notwithstanding the serious health risks, tetraethyl lead quickly captured the market and by summer 1925, 1.1 billion litres of leaded fuel had been sold. It took until the mid-1970s before the US began phasing out leaded gasoline. In the European Union, leaded fuel was finally banned on 1 January 2000 (Kitman 2000).

\section{THE SECOND INVENTION}

With his second great invention, Thomas Midgley Jr. indeed revolutionised everyday life around the world and perhaps even saved many human lives. He succeeded in developing cheaper and, above all, safer refrigerators. In the late 1920s, compounds like ammonia, methyl chloride or sulfur 

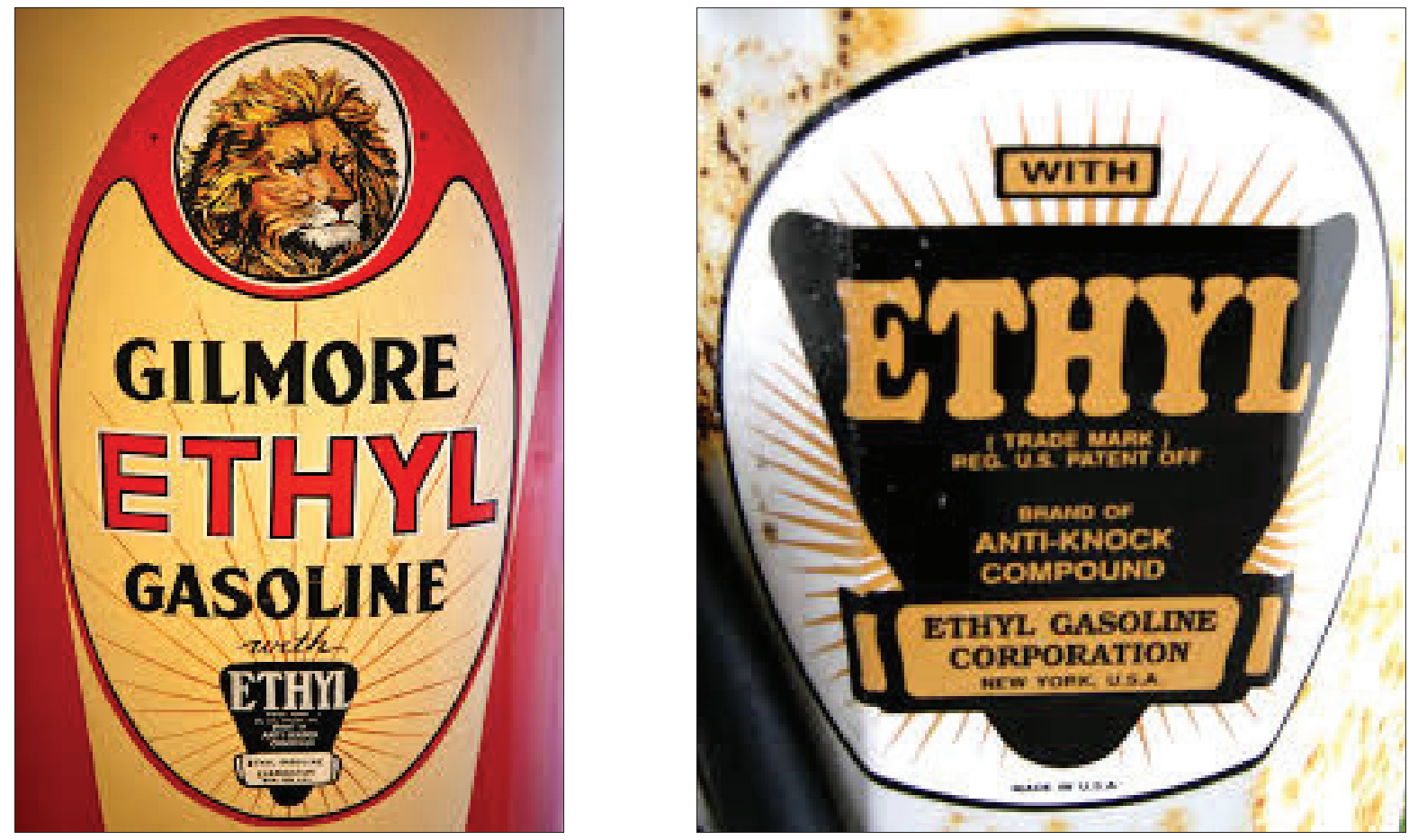

PLATE 2 - Promotional signs for leaded fuel on gasoline pumps.
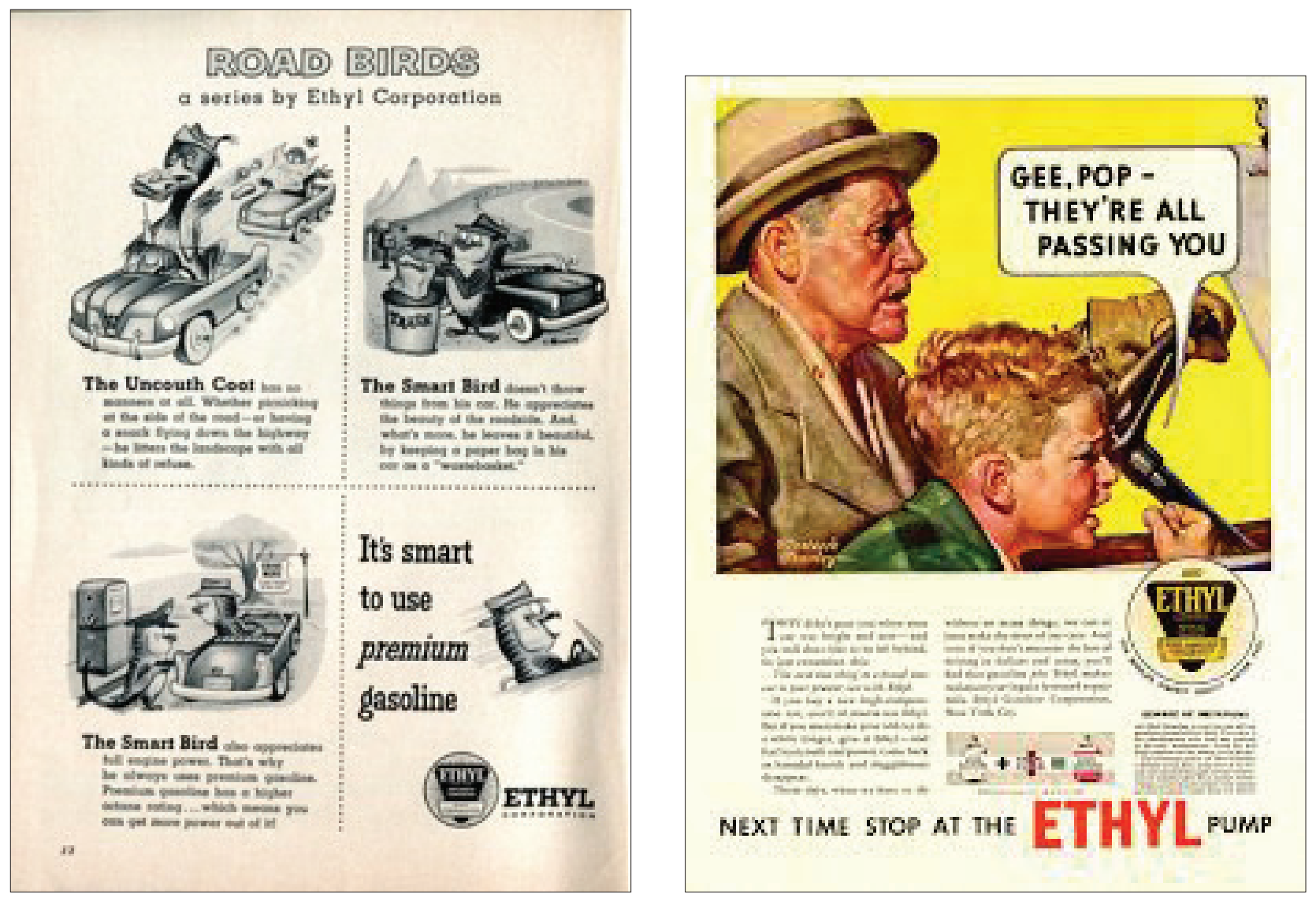

PLATE 3 - Newspaper advertisements for the Ethyl Gasoline Corporation. 
dioxide were employed as refrigerants in air conditioning and refrigeration systems. All these gases were either toxic, highly flammable or even explosive. The smallest leakage could result in serious illness, injury or even death.

It was Midgley who first developed a gas that replaced the numerous toxic or explosive substances previously used as refrigerants and made refrigerators safe. His new refrigerant was non-toxic and not flammable, namely dichlorodifluoromethane (Midgley IV 2001). It was the first of the chlorofluorocarbons, better known as CFCs. The CFCs form a class of chemical compounds in which some or all hydrogen atoms in hydrocarbons are replaced by chlorine and fluorine atoms. Dichlorodifluoromethane is more commonly referred to as "Freon 12". It is derived from methane, which has the composition $\mathrm{CH}_{4}$. Figure 2 shows that in Freon 12 two chlorine and two fluorine atoms are bonded to the carbon instead of the four hydrogens.

Once again, Midgley did not back off from taking personal risks to substantiate the importance of his discovery. In 1930, he inhaled a lungful of Freon 12 and then blew out a lit candle to show the American Chemical Society that CFC was absolutely non-toxic and non-flammable (Midgley IV 2001). CFCs soon became the refrigerant of choice, and by 1950 more than $80 \%$ of American farms and more than $90 \%$ of urban homes had a CFC-cooled refrigerator (Krasner-Khait 2000). Moreover, Freon 12 and other CFCs were fantastically successful in other applications, such as air conditioning, fire extinguishers and as propellants in aerosol spray cans. The Society of Chemical Industry awarded Midgley the Perkin Medal in 1937 for his work (CoEN News 2008).

Midgley died three decades before the ozone-depleting ( $c f$. pl. 4) and greenhouse gas effects of CFCs in the atmosphere became widely known. In 1974, the American scientists Mario Molina und Frank Rowland warned against the global threat originating from CFCs (Molina \& Rowland 1974). The Montreal Protocol was signed in 1987 and in March 1988 DuPont agreed to reduce and eliminate CFC production. Worldwide production of CFCs was totally phased out by 2005.

In summary, Thomas Midgley Jr. made two inventions which had a fatal impact on the Earth's atmosphere. At the time of his discoveries, Midgley was a highly esteemed American national hero. He held two honorary degrees and in 1941 the American Chemical Society gave him its highest award, the Priestly Medal. In 1944 he was elected president of the American Chemical Society. William Lloyd Evans acknowledged his merits with the words: "In a wonderful way Thomas Midgley Jr. made life more enjoyable. The after-world will appreciate the enduring value of his research"(Spiegel Online 2014). Today, his legacy is viewed mainly with criticism. Midgley's inventions became an incarnation for the threats to our planet (Bryson 2012). The historian John McNeill remarked that Midgley "had more impact on the atmosphere than any other single organism in Earth's history" (McNeill 2001). A cartoon even portrayed him as the "worst scientist ever" (Doyle \& Brozyna 2013).

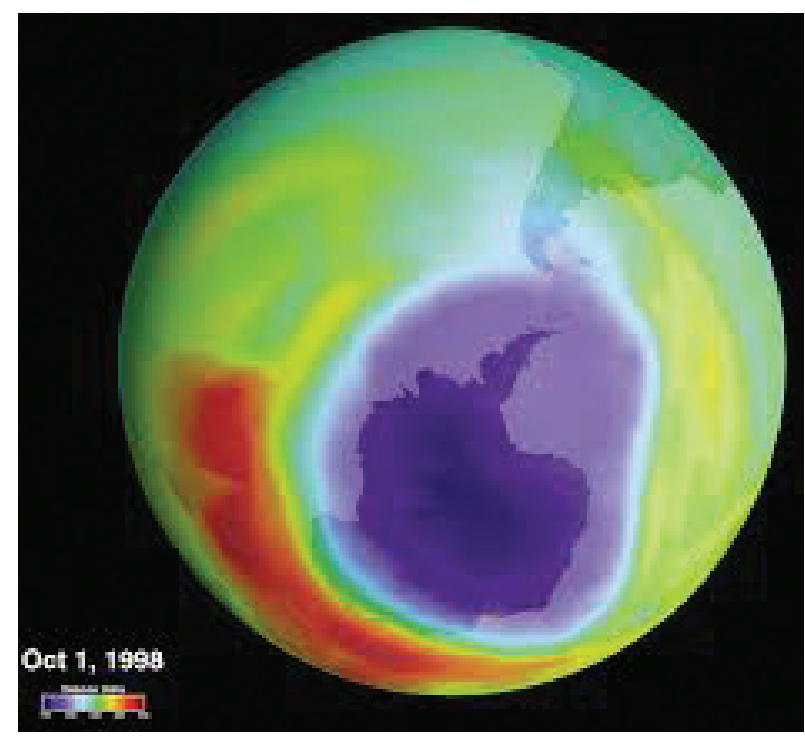

PLATE 4 - Hole in the ozone layer over Antarctica (Source: http://grin.hq.nasa.gov).

\section{THE END}

In 1940, at the age of 51, Midgley contracted polio, which left him severely disabled. This led him to devise an elaborate system of strings and pulleys to help others lift him from his bed. This system was the eventual cause of his own death when he became entangled in the ropes of this device and died of strangulation at the age of 55. This happened on 2 November 1944, in Worthington, Ohio (Bryson 2012, Wiener Zeitung 2014, Spiegel Online 2014). In all, Thomas Midgley Jr. was a tragic figure. We are still living with the consequences of his inventions and will for many years to come.

\section{ACKNOWLEDGEMENTS}

This paper was presented at the Biennial Conference of the Australian Association of von Humboldt Fellows ("Global Perspectives, Local Knowledge”) in Hobart, Tasmania, 20-22 November 2015. Thanks are due to Professor John W. Gilje, James Madison University, Harrisonburg, USA, for critically reading the manuscript.

\section{REFERENCES}

ACS 2016: Nichols Medalists, American Chemical Society, http:// newyorkacs.org/nicholsmedalists.html (accesssed 10 January 2016).

Bryson, B. 2012: A Short History of Nearly Everything. Doubleday, Canada.

C\&EN News 2008: The Priestly Medalists, 1923-2008, CerEN News 86: 60-61.

Doyle, J. \& Brozyna, A. 2013: Young Scientist's Guide to Faulty Freaks of Nature. Gibbs M. Smith Inc.: 160 pp.

Kettering, C.F. 1947: Biographical Memoir of Thomas Midgley 1889-1944. National Academy of Science USA Biographical Memoirs, 24: 359-380. 
Kitman, J.L. 2000: The Secret History of Lead. The Nation (newspaper) of 20 March 2000, http://www.thenation. com/article/secret-history-lead/.

Krasner-Khait, B. 2000: The Impact of Refrigeration, History Magazine Feb./Mar. 2000, http://www.history-magazine. com/refrig.html.

Markowitz, G. \& Rosner, D. 2003: Deceit and Denial: The Deadly Politics of Industrial Pollution (California/Milbank Books on Health and the Public), University of California Press, USA: $428 \mathrm{pp}$.

McNeill, J.R. 2001: Something New Under the Sun: An Environmental History of the Twentieth-Century World, Norton, New York, USA: 421 pp.

Midgley IV, T. 2001: From the Periodic Table to Production: The Life of Thomas Midgley, Jr., the Inventor of Ethyl Gasoline and Freon Refrigerants. Stargazer Publishing Company, Corona CA, USA: $174 \mathrm{pp}$.

Midgley Jr., T. 1926: Prevention of Fuel Knock, US patent No. U.S. 1,571,862 (2 February 1926).
Midgley Jr., T. 1942: A critical examination of some concepts in rubber chemistry. Science 96: 143-164.

Molina, M.J. \& Rowland, F.S. 1974: Stratospheric sink for chlorofluoromethanes: chlorine atom-catalysed destruction of ozone. Nature 249: 810-812.

Spiegel Online newspaper 2014: Der Mann, der fast die Menschheit auslöschte (und sich am Ende selbst strangulierte). Article dated 16 May, http://www.spiegel.de/einestages/fckwerfinder-thomas-midgley-schuld-am-ozonloch-a-968979. html.

Wiener Zeitung newspaper (Vienna) 2014: Sorcerer's Apprentice of modern age. Article dated 2 November, http://www. wienerzeitung.at/themem_channel/wz_reflexionen/ vermessungen/686056_Zauberlehrling-der-Moderne.html

Wikipedia 2016: Thomas Midgley Jr., https://en.wikipedia.org/ wiki/Thomas_Midgley,_Jr. (accessed 10 January 2016).

(Accepted 7 June 2016) 
